\title{
DINAMIKA POLITIK PENGAMBILAN KEBIJAKAN PEMBENTUKAN DUA DINAS PENDIDIKAN DI KABUPATEN BANTUL
}

\author{
Supriyanto \\ Alumni S2 MP PPs UNY, \\ email: priyantouny@yahoo.com
}

\begin{abstract}
Abstrak: Dinamika Politik Pengambilan Kebijakan Pembentukan Dua Dinas Pendidikan di Kabupaten Bantul. Penelitian ini bertujuan untuk mengungkapkan latar belakang, dinamika politik yang terjadi dan implikasi politik yang ditimbulkan dalam pengambilan kebijakan pembentukan dua dinas pendidikan di Kabupaten Bantul. Penelitian ini tergolong sebagai analisis kebijakan yang menggunakan pendekatan kualitatif. Pengumpulan data dilakukan melalui interview dan studi dokumen. Subjek penelitian ini terdiri atas pejabat-pejabat eksekutif di pemerintah daerah Kabupaten Bantul, pimpinan dan anggota DPRD Bantul dan kelompokkelompok kepentingan di Kabupaten Bantul. Keabsahan data dilakukan dengan triangulasi. Analisis data yang digunakan adalah model analisis interaktif Miles dan Huberman melalui kegiatan pengumpulan data, reduksi data, penyajian data, dan penarikan kesimpulan. Hasil penelitian menunjukan bahwa: (1) Pengambilan kebijakan pembentukan dua dinas pendidikan di Kabupaten Bantul memiliki latar belakang politis untuk memberikan perimbangan kekuasaan bidang pendidikan untuk ormas Islam Nahdatul Ulama (NU) dan Muhammadiyah, secara normatif adanya kewenangan bagi bupati pascaotonomi daerah untuk mengelola bidang pendidikan sesuai karakteristik, kebutuhan dan kemampuan daerah, dan secara fungsional rendahnya kinerja dinas pendidikan; (2) Dinamika politik dalam proses pembentukan dua dinas pendidikan di Kabupaten Bantul menunjukan bahwa kekuatan politik informal lebih dominan daripada kekuatan politik formal dalam memberikan pengaruh terhadap pengambilan kebijakan pembentukan dua dinas pendidikan; dan (3) Pembentukan dua dinas pendidikan menyebabkan berkembangnya budaya spoil system atau patronage system yang berimplikasi pengangkatan pejabat struktural di dua Dinas Pendidikan lebih karena pertimbangan faktor kesamaan golongan.
\end{abstract}

Kata Kunci: dinamika politik, kebijakan pembentukan dua dinas pendidikan, dinas pendidikan.

\footnotetext{
Abstract: The Dynamics of Political Policy Decision in The Formation of Two Department of Education in Bantul Regency. This research is aimed to reveal the background, the political dynamics and political implications arising in the policy making establishment of two department of education in Bantul. This research was classified as policy analysis, which used a qualitative approach. Data collection was conducted through interviews and document research. The research subjects consisted of executive officials in the Bantul local government, leaders, and members of parliament Bantul, and interest groups in Bantul. Data validation was done by triangulation. Analysis of the data used is the model of Miles and Huberman interactive analysis through data collection, data reduction, data display, and conclusion. The results showed that: (1) the policy-making establishment of two "department of education" in Bantul have a political background to provide the balance of power in education for Muslim organizations Nahdlatul Ulama (NU) and Muhammadiyah, which are normative for the governors the authority after the regional autonomy to administer education according to the characteristics, needs and abilities of the region, and that the poor performance of the functional departments of education; (2) The political dynamics in the process of establishing two in Bantul district education
} 
office shows that the dominant political force is more informal than formal political power in giving effect to the policy-making establishment of two offices of education, and (3) Establishment of two education departments led to the development of culture systems or spoil patronage system that implicates structural appointments in the Department of Education two more due consideration of the similarity factor group.

Keywords: political dynamics, policy establishment of two education department, education department.

\section{PENDAHULUAN}

Desentralisasi pendidikan adalah sebuah proses yang kompleks dan dapat membawa perubahan-perubahan penting tentang cara sistem pendidikan menciptakan kebijakan (Didi Supriyadi, 2009: 37). Desentralisasi pendidikan memberikan kewenangan penuh bagi pemerintah daerah untuk mengatur sistem pengelolaaan pendidikan di daerahnya sesuai dengan karakteristik, kebutuhan, kemampuan perekonomian, kondisi sosial, politik, budaya, dan kemampuan daerahnya. Pada akhirnya desentralisasi pendidikan berimplikasi pada lokalisasi pembuatan kebijakan pendidikan karena setiap daerah berwenang membuat kebijakanya sendiri.

Desentralisasi pendidikan dalam bentuk pelimpahan kewenangan pengelolaan bidang pendidikan dari pemerintah pusat kepada pemerintah daerah pada dasarnya diterapkan untuk peningkatan mutu pendidikan. Salah satu daerah yang berhasil meningkatkan mutu pendidikannya pascaberlakunya kebijakan desentralisasi adalah kabupaten Bantul. Keberhasilan Pemerintah Daerah (Pemda) Kabupaten Bantul dalam pengelolaan bidang pendidikan dan ditopang adanya kewenangan yuridis pascaotonomi daerah untuk mengelola pendidikan di daerah, membuat Pemda Bantul semakin terpacu untuk terus melakukan inovasi demi meningkatkan mutu pendidikan daerah. Salah satu terobosan yang diambil yakni inovasi struktur kelembagaan pendidikan dengan membentuk dua lembaga/dinas yang mengelola bidang pendidikan. Pembentukan dua dinas pendidikan di kabupaten Bantul merupakan satu-satunya model kelembagaan pendidikan di Indonesia.
Kebijakan pemerintah daerah Kabupaten Bantul yang membentuk dua dinas pendidikan patut untuk dicermati mengingat sebelumnya belum ada daerah lain di Indonesia yang mengambil kebijakan serupa. Selain itu, menurut Agus Effendi, selama ini belum ada landasan yuridis yang secara jelas mengatur dan menjelaskan bahwa dalam satu bidang pemerintahan daerah boleh dikelola oleh dua Dinas/SKPD (anggota fraksi PKS DPRD Bantul, Interview pra research, 10 Maret 2010). Oleh karena itu, pembentukan dua lembaga dinas pendidikan dikhawatirkan akan menimbulkan improvisasi terhadap undang-undang/dasar hukum yang lebih tinggi.

Permasalahan lainya seperti dinyatakan Tri Wuryani bahwa sebenarnya dari segi penganggaran Pemda Bantul masih belum mampu untuk membiayai dua dinas pendidikan karena alokasi pendanaan dari pemerintah pusat hanya untuk satu lembaga Dinas Pendidikan (mantan anggota DPRD Bantul dan sekretaris fraksi Kesatuan Baru DPRD Bantul, Interview pra research, 30 Maret 2010). Bahkan lembaga resmi pemerintah yang mengelola bidang pendidikan dan memiliki kedudukan struktural lebih tinggi dibanding dinas pendidikan Bantul Dinas Pendidikan DIY juga hanya terdiri dari satu lembaga.

Berbagai permasalahan terkait pembentukan dua dinas pendidikan tidak menyurutkan niat Pemda Bantul untuk tetap mengambil kebijakan membentuk dua dinas pendidikan. Keberanian Pemda Kabupaten Bantul untuk mengambil langkah politik tersebut menimbulkan pertanyaan besar. Apakah pengambilan kebijakan yang "tidak umum" tersebut adalah sebagai upaya 
pemerintah daerah untuk meningkatkan mutu pendidikan atau sekadar langkah politik yang diambil karena adanya motifmotif politik atau tujuan politik tertentu dari pengambil kebijakan. Oleh karena itu, untuk mengetahui dinamika politik dalam pengambilan kebijakan pembentukan dua dinas pendidikan maka perlu dilakukan analisis kebijakan khususnya analisis tentang proses kebijakan. Secara akademik urgensi kajian politik dalam studi analisis kebijakan dinyatakan Subarsono (2009:23), bahwa bagian dari analisis kebijakan yang selama ini kurang mendapat perhatian tetapi justru sangat krusial adalah proses politik pengambilan kebijakan yang meliputi tahap penyusunan agenda kebijakan dan formulasi kebijakan (perumusan masalah). Pentingnya penelitian tentang proses politik dalam studi analisis kebijakan juga dinyatakan oleh Ace Suryadi dan HAR Tilaar (1993: 48), yang menyatakan bahwa proses politik dari analisis kebijakan merupakan subyek yang seharusnya diteliti di dalam studi analisis kebijakan.

Berdasarkan latar belakang masalah seperti dipaparkan di atas maka rumusan masalah dalam penelitian ini adalah 1) apa yang melatarbelakangi pembentukan dua dinas pendidikan di Kabupaten Bantul?; 2) bagaimana dinamika politik dalam proses pembentukan dua dinas pendidikan di Kabupaten Bantul?; 3) bagaimana implikasi politik pembentukan dua dinas pendidikan di Kabupaten Bantul? Tujuan penelitian ini adalah untuk menjawab tiga permasalahan tersebut.

Terkait dengan sistem politik, Robert Dahl menjelaskan bahwa sistem politik sebagai pola yang tetap dari hubungan manusia yang melibatkan makna yang luas dari kekuasaan, aturan-aturan dan kewenanganya (Toni Andrianus Pito dkk, 2006:45). Sistem politik mempunyai fungsi-fungsi tertentu untuk masyarakat, yakni membuat keputusan-keputusan kebijakan (policy decisions) yang mengikat mengenai alokasialokasi dari nilai-nilai (baik yang bersifat materiil maupun non-materiil). Keputusan-keputusan kebijakan yang dihasilkan merupakan output yang sifatnya mengikat dan diarahkan kepada tercapainya tujuan masyarakat (Miriam Budiardjo, 2008:58).

Sistem politik adalah sistem terbuka karena pengaruh-pengaruh dari luar (sistem lain) bisa masuk, berinteraksi dan berproses didalamnya. Proses dalam sistem politik secara umum dapat dijelaskan sebagai input dan output, yang diwarnai suatu pola interaksi antara sistem politik dan lingkungan. Input (yang berasal dari lingkungan) adalah tuntutan serta aspirasi dari masyarakat dan dukungan masyarakat. Input tersebut kemudian diolah dan diubah (conversion) menjadi output yang berupa keputusan-keputusan dan kebijakan-kebijakan yang mengikat dari pemerintah.

Proses pengambilan kebijakan selalu diwarnai dengan konflik-konflik politik. Ramlan Surbakti, (1993:153) menjelaskan bahwa konflik politik yang terjadi antar kelompok dalam proses pengambilan sebuah kebijakan pada dasarnya karena masingmasing kelompok berupaya keras untuk mendapatkan dan/atau mempertahankan sumber yang sama dan jumlahnya terbatas, misalnya jabatan politis, kekuasaan, pengaruh ataupun legitimasi dan pengakuan dari masyarakat. Konflik politik berakhir manakala telah tercapai suatu consensus bersama antar aktor politik dalam suatu pengambilan kebijakan.

Kebijakan publik adalah kebijakan yang dikembangkan oleh lembaga-lembaga pemerintah dan pejabat-pejabat pemerintah yang dipengaruhi oleh faktor-faktor bukan pemerintah (Budi Winarno, 2005: 17). Kebijakan pendidikan pada dasarnya merupakan kebijakan publik dalam bidang pendidikan. Dengan demikian, pada dasarnya proses pembuatan kebijakan pendidikan bukan menjadi monopoli birokrasi pemerintah yang mengurusi pendidikan akan tetapi kekuatan-kekuatan diluar itu pun bisa memberikan pengaruh.

Dalam penyusunan agenda kebijakan pendidikan, proses masuknya suatu isu menjadi agenda kebijakan merupakan suatu proses yang memiliki dosis politik sangat 
tinggi, yang berlangsung dalam lingkungan pemerintahan. Pemerintah yang sedang berkuasa kadang kala menggunakan kekuatannya untuk menggagalkan sebuah issue yang sedang muncul ke permukaan masuk kedalam kebijakan. Setelah suatu isu berhasil masuk menjadi agenda kebijakan maka tahap berikutnya adalah formulasi kebijakan pendidikan.

Menurut Soenarko (2000: 132), formulasi kebijakan merupakan kegiatan perencanaan dengan meletakan keputusan-keputusan hasil analisis masalah dalam rancangan kebijakan pemerintah. Dalam proses formulasi kebijakan tidak semua aktor pasti terlibat dalam perumusan kebijakan.

Dalam sistem pemerintahan desentralistis yang ditandai dengan adanya otonomi daerah berimplikasi padaa banyaknya aktor, institusi, dan budaya lokal bermunculan kembali dan mulai memainkan peran di dalam politik lokal. Aktor-aktor lokal yang teroganisir dan memiliki simbol kultural lokal kembali berada di panggung politik. Bahkan di beberapa daerah efeknya cukup sigifikan, yaitu pelaku politik seperti pemda, politisi lokal, organisasi nonpemerintah (NGOs), dan elite lokal sering menjadi immune terhadap intervensi dari pusat.

Selain itu penyelenggaran sistem desentralisasi yang memberikan kewenangan sangat besar kepada kepala daerah menyebabkan pola perilaku birokrasi pendidikan di daerah semakin bersifat patrimordialisme (patron-client). Pola ini menunjukan bahwa perilaku dan mentalitas sebagai penguasa yang harus dilayani daripada aparat yang harus melayani publik. Pola hubungan yang terjadi masih bersifat personal, dimana faktor kedekatan dan loyalitas lebih dikedepankan daripada aturan-aturan legal formal. Oleh karena itu, yang terjadi adalah hubungan yang bersifat personal, berdasarkan pertemanan, dan like and dislike dalam promosi jabatan ataupun rekrutmen pejabat daerah (Lili Romli, 2007:81).

\section{METODE}

Penelitian ini menggunakan pendekatan kualitatif. Setting yang diambil adalah birokrasi di lingkungan Pemda Kabupaten Bantul dan DPRD Kabupaten Bantul. Subjek penelitian diambil dengan purposive yakni Bupati selaku pengambil kebijakan di lingkungan pemerintah daerah kabupaten Bantul dan jajaran birokrasi terkait, (2) pimpinan dan anggota DPRD, (3) kelompokkelompok non pemerintahan yang dapat mempengaruhi pengambilan suatu kebijakan.

Pengumpulan data dilakukan dengan teknik wawancara mendalam (in-depth interview) untuk memperoleh data primer dan dengan teknik studi dokumentasi untuk memperoleh data sekunder. Uji keabsahan data yang dilakukan meliputi uji kredibilitas data dengan teknik triangulasi, yaitu teknik pengecekan data dari berbagai sumber dengan berbagai cara dan berbagai waktu (Sugiyono, 2009:273. Analisis data dilakukan dengan metode nonstatistic yakni menggunakan model interaktif yang meliputi reduksi data, display data, dan penarikan kesimpulan.

\section{HASIL DAN PEMBAHASAN}

\section{Latar Belakang Pembentukan Dua Di-} nas Pendidikan di Kabupaten Bantul

Pembentukan dua dinas pendidikan merupakan salah satu kebijakan strategis di bidang pendidikan yang dibuat oleh pemerintah Kabupaten Bantul. Kebijakan tersebut secara formal ditetapkan dalam Perda No. 16 Tahun 2007 tentang Pembentukan Organisasi Dinas Daerah di Lingkungan Pemerintah Kabupaten Bantul. Pasal 3 poin 1 dan 2 dalam Perda tersebut menyebutkan bahwa dinas yang mengelola bidang pendidikan akan menjadi dua dinas yakni Dinas Pendidikan Dasar dan Dinas Pendidikan Menengah dan Non Formal.

Pembentukan dua dinas pendidikan di Kabupaten Bantul sarat dengan berbagai macam kepentingan politis. Pola interaksi dan wacana politik yang berkembang pada tingkat lokal menunjukkan bahwa kebijakan tersebut muncul sebagai respons sistem politik terhadap adanya dinamika politik antara dua kel- 
ompok kepentingan yang dalam hal ini ormas Islam Nahdatul Ulama (NU) dan ormas Islam Muhammadiyah. Hal ini seperti dinyatakan oleh salah seorang pimpinan DPRD Bantul: "Secara politis pembentukan dua dinas pendidikan itu ada unsur pembagian "kekuasaan" bagi Muhammadiyah dan bagi NU karena mereka dulu sama-sama mendukung pak Bupati" (HK/3 Maret 2010).

Kuatnya aspek politis juga dinyatakan oleh sekretaris fraksi Kesatuan Baru DPRD Bantul:

Kalau boleh jujur sebenarnya pembentukan dua dinas pendidikan menimbulkan banyak pro dan kontra, terutama masalah anggaran karena sebenarnya Bantul masih kekurangan anggaran untuk itu. Tapi Bupati selaku pengambil kebijakan mungkin punya pertimbangan siapa saja orang yang dianggap berjasa "untuk Bantul" sehingga memutuskan hal tersebut. Jadi nuansa politis bermain di dalamnya. Tapi meskipun begitu, kami sebagai pengusung pak Bupati tetap mendukung kebijakan beliau sebagai konsekuensi politik yang kami pilih (TW/5 September 2010).

Kedua kelompok ormas Islam tersebut mengajukan keinginan yang sama kepada Bupati yakni agar jabatan kepala di dinas pendidikan diberikan kepada kadernya yang potensial dan telah berkarier di Satuan Kerja Pemerintah Daerah (SKPD) tersebut. Hal ini seperti diutarakan oleh ketua umum Pengurus Cabang Nahdatul Ulama (PCNU) Kabupaten Bantul: "Kami menginginkan kader NU menjabat sebagai kepala dinas pendidikan" (HJ/6 Oktober 2010). Hal senada diungkapkan oleh ketua Pengurus Daerah Muhammadiyah (PDM) Bantul: "Sudah seharusnya jabatan kepala dinas pendidikan diserahkan kepada Muhammadiyah karena kepemilikan audience dan publik pendukung paling banyak dari Muhammadiyah" (AM/9 Oktober 2010).

Kuatnya bargaining position yang dimiliki NU dan Muhammadiyah mem- buat keinginan kedua ormas Islam tersebut mendapat respons positif dari Bupati selaku pengambil kebijakan. Hal ini karena keduanya memiliki peran yang sangat besar dalam mendukung Bupati menjalankan pemerintahan dan samasama memiliki hubungan kedekatan dengan Bupati baik dalam posisi selaku kepala daerah atau selaku pribadi. Faktor inilah yang kemudian membuat Bupati mewacanakan ide pembentukan dua dinas pendidikan.

Pembentukan dua Dinas Pendidikan dilatarbelakangi motif politik $\mathrm{Bu}$ pati untuk memberikan perimbangan "kekuasaan" dalam bidang pendidikan bagi NU dan Muhammadiyah. Hal ini sebagaimana dinyatakan oleh ketua umum Pengurus Cabang Nahdatul Ulama (PCNU) Kabupaten Bantul:

Pemisahan Dinas Pendidikan menjadi dua adalah strategi pak Bupati. Pak Bupati mengambil sikap, biar tidak timbul "kegegeran", biar tidak kehilangan dukunganya dari NU dan Muhammadiyah maka Dinas Pendidikan dipisah saja. Dinas Pendidikan Bantul dipisah jadi Dikdas dan Dikmenof agar suasana kondusif. Jadi biar ada keseimbangan, untuk mengakomodir kepentinganya maka Dikdas untuk Muhammadiyah dan Dikmenof untuk NU" (HJ/6 Oktober 2010).

Pengakuan senada juga diungkapkan oleh ketua Pengurus Daerah Muhammadiyah (PDM) Bantul: "Pemda mempertimbangkan agar berimbang; "masak Muhammadiyah dikasih kok NU tidak". Jadi ini lebih kearah perimbangan saja" (AM/9 Oktober 2010).

Tindakan tersebut merupakan upaya politis Bupati dalam rangka mengakomodasi suara dari kedua ormas Islam tersebut. Hal tersebut dilakukan dengan tujuan agar dapat mempertahankan dukungan politis dari kedua ormas tersebut dan mencegah terjadinya pertentangan (konflik) dan kecemburuan antara keduanya yang dikhawatirkan akan merugikan posisi politik Bupati. Maka langkah 
yang dianggap sebagai win-win solution dan bisa diterima oleh kedua kelompok adalah memecah dan membentuk dinas pendidikan menjadi dua dan jabatan kepala dinas diberikan kepada staff dinas yang merupakan kader dari masingmasing ormas. Harapannya dengan solusi tersebut kedua ormas bisa terus memperkuat dukungan dan legitimasi politik Bupati.

Kondisi tersebut menunjukkan bahwa Bupati memiliki kepentingan dan misi politik di balik idenya untuk membentuk dua dinas pendidikan. Pembentukan dua dinas pendidikan mencerminkan terjadinya kebijakan birokratisasi yang menganut paham Parkinsonisasi, yakni pemekaran struktur dinas pendidikan bukan karena kebutuhan yang senyatanya tetapi karena tujuan politik. Pembentukan dua dinas pendidikan dipergunakan sebagai instrument untuk memperoleh dan mempertahankan dukungan politik. pembentukan dua dinas pendidikan pada dasarnya merupakan wujud akumulasi kekuasaan melalui birokrasi yang dilakukan pemegang status quo untuk mempertahankan kekuasaan.

Pembentukan dua dinas pendidikan selain mencerminkan strategi Parkinsonisasi birokrasi juga diikuti secara sistematis dengan gejala Orwelisasi. Penguasa menjadikan birokrasi dinas pendidikan sebagai instrument politik dan alat kontrol politik atau dengan kata lain menjadikan birokrasi Dinas Pendidikan hanya sebagai perpanjangan tangan (extention) penguasa untuk mengontrol masyarakat. Masyarakat dalam hal ini adalah konstituen Nahdatul Ulama (NU) dan Muhammadiyah. Oleh karena itu, dapat dikatakan bahwa keputusan Bupati untuk mengakomodasi keinginan ormas NU dan Muhammadiyah pada dasarnya mengindikasikan ketidakberanian Bupati dalam menghadapi resiko negatif berupa melemahnya dukungan politik dari kedua ormas tersebut.
Selain itu, langkah Bupati mengakomodasi kepentingan dua kelompok ormas Islam dengan jalan memberikan jabatan kepala dinas pendidikan bagi kader-kader dari kedua ormas tersebut merupakan wujud "balas jasa" atas besarnya dukungan kedua ormas tersebut dalam suksesi pemenangan dan pemerintahan Bupati. Hal ini menunjukkan kebijakan pembentukan dua dinas pendidikan juga dilatarbelakangi oleh adanya politik utang budi dari penguasa kepada pihak yang berjasa yang dalam hal ini ormas Islam NU dan Muhammadiyah.

Apa yang dikemukakan di atas sekaligus menunjukkan bahwa jabatan struktural kepala dinas pada dua dinas pendidikan di Kabupaten Bantul merupakan jabatan yang dipolitisasi. Adanya jabatan itu adalah untuk memberi ruang bagi aspirasi tokoh-tokoh atau lembaga kegamaan. Jabatan itu bukan semata karena kebutuhan tapi untuk meredam agar tidak terjadi pergolakan politik yang bisa merongrong kekuasaan pemegang status quo. Jadi, Bupati berusaha memegang kendali atas dua basis masa yang samasama kuat di Bantul.

Motif-motif politis yang melatarbelakangi pembentukan dua dinas pendidikan tidak memungkinkan untuk diangkat ke permukaan sebagai isu kebijakan dan dijadikan sebagai dasar pertimbangan kebijakan pembentukan dinas pendidikan. Oleh karena itu, pengambil keputusan mencoba membuat, mengkaji, dan memunculkan pertimbangan-pertimbangan yang sifatnya normatif dan fungsional untuk meligitimasi wacana tersebut. Dengan pertimbangan yang logis dan dapat dipertanggungjawabkan kepada publik maka lebih memungkinkan ide tersebut dapat terangkat menjadi isu dan agenda kebijakan sehingga dapat dilanjutkan untuk dibahas di DPRD.

Adapun pertimbangan normatif yang digunakan Pemda Bantul ketika mengajukan pembentukan dua SKPD dinas pendidikan adalah kewenangan yuridis 
formal yang tertuang dalam UU No. 32 tahun 2004 tentang Pemerintah Daerah yang secara eksplisit memberikan otonomi yang luas kepada pemda untuk mengatur, mengurus, dan mengelola daerahnya sesuai karakteristik, kemampuan, dan kebutuhan daerah. Dalam peraturan perundangan tersebut ditetapkan bahwa pendidikan merupakan salah satu bidang dari kesebelas bidang yang didesentralisasikan dari pemerintah pusat kepada pemerintah daerah. Peraturan perundang-undangan tersebut yang kemudian dijadikan dasar bahwa Pemda Bantul dengan persetujuan DPRD berhak mengatur daerahnya sendiri dalam merencanakan kelembagaan SKPD (dinas) dinas pendidikan.

Pertimbangan nomatif lainnya adalah bahwa pembentukan dua dinas pendidikan merupakan bentuk komitmen Pemda Bantul dalam memajukan pendidikan daerah sesuai amanat Rencana Pembangunan Jangka Menengah Daerah (RPJMD) yang berupaya mendudukkan sektor pendidikan sebagai prioritas utama dalam pembangunan daerah. Selain itu kebijakan tersebut juga dilakukan untuk mendukung dan menyukseskan kebijakan nasional program wajib belajar 9 tahun dan kebijakan wajar daerah 12 tahun. Jadi pembentukan dua dinas pendidikan dianggap sebagai salah satu strategi kelembagaan yang diambil pemerintah daerah untuk memajukan pendidikan di Kabupaten Bantul. Secara normatif pengambilan kebijakan tersebut juga menunjukkan keberanian Bupati Bantul untuk melakukan hal yang berbeda dari kelaziman dibandingkan daerah lain di era otonomi daerah dalam rangka memajukan pendidikan.

Sementara pertimbangan fungsional yang disampaikan Pemda Bantul adalah rendahnya kinerja dinas pendidikan. Dinas pendidikan dianggap belum mampu menjalankan tugas pokok dan fungsinya (tupoksi) dengan baik sehingga tidak berhasil mencapai target yang ditetapkan. Hal ini sebagaimana dinyatakan oleh Bupati Bantul:

Saya mencermati secara intensif selama 6 tahun terakhir, semua SKPD (Dinas) yang paling memprihatinkan adalah Dinas Pendidikan. Saya maklum, waktu mereka mengajukan anggaran, sangat memprihatinkan sekali, hanya sekadar membatalkan tugas kewajiban saja, bahkan ketika saya kejar-kejar pun sangat sulit. Tapi saya memahami karena sangat besarnya organisasinya, waktu masih jadi satu dispen hanya dengan satu kadin (eselon 2), eselon 3 enam orang, 100-an eselon empat, mereka harus mengurusi tugas yang sangat banyak, sehingga ketika mengurusi anggaran sangat banyak, akibatnya ketika mem-breakdown anggaran jadi "sak-sak'e" (sekedar jadi tanpa melihat kualitas) dan Dinas Pendidikan sangat kacau balau managemen-nya, dll. Saya cari apa penyebabnya, ternyata karena beban kerja yang berlebihan. Rendahnya kinerja yang disebabkan beban kerja berlebih tersebut akan dapat diatasi dengan cara memisah Dinas Pendidikan menjadi 2 (dua) SKPD (IS/4 September 2010).

Penyebab dari rendahnya kinerja dinas pendidikan tersebut adalah karena volume pekerjaan yang ada terlalu besar, beban tugas dan kerja terlalu berat, rentang kendali terlalu panjang, jumlah Sumber Daya Manusia (SDM) kurang proporsional dibanding banyaknya pekerjaan, dan badan organisasi terlalu besar. Berdasarkan pertimbangan tersebut maka pemerintah daerah mengajukan secara resmi rencana pembentukan dua SKPD dinas pendidikan. Kebijakan pembentukan dua dinas pendidikan diambil sebagai bentuk inovasi kelembagaan dalam rangka memperbaiki kinerja SKPD dinas pendidikan.

\section{Dinamika Politik Proses Pembentu- kan Dua Dinas Pendidikan di Kabu- paten Bantul}

Dinamika pembentukan dua dinas pendidikan di Kabupaten Bantul tidak 
dapat dilepaskan dari keberadaan kelompok-kelompok nonpemerintah yang memiliki andil besar dalam melatarbelakangi pengambilan kebijakan tersebut. Proses pengambilan kebijakan dipengaruhi dinamika politik yang melibatkan dua ormas Islam, yakni Nahdatul Ulama (NU) dan Muhammadiyah. Kedua ormas tersebut memiliki keinginan untuk mendudukkan kadernya menjadi kepala dinas pendidikan. Hal ini tercermin dari pernyataan ketua PCNU Bantul: "Kami menginginkan dinas pendidikan untuk mengakomodir konstituen NU Bantul dan agar memiliki "lahan" untuk pengembangan dakwah" (HJ/6 Oktober 2010). Hal senada juga diungkapkan oleh ketua PDM Bantul: "Muhammadiyah menghendaki dan senang kalau kadernya menduduki posisi strategis di lembaga pemerintahan, termasuk bidang pendidikan, karena bisa menjadi sarana dakwah" (AM/9 Oktober 2010).

Berdasarkan pernyataan-pernyataan tersebut diketahui bahwa kedua ormas tersebut ingin mendudukkan kadernya sebagai kepala di dinas pendidikan dengan tujuan untuk mempermudah "penggunaan" dinas pendidikan sebagai "kendaraan" dakwah. Hal tersebut sangat beralasan mengingat dinas pendidikan adalah unsur pelaksana pemerintahan daerah di bidang pendidikan sehingga memiliki kewenangan resmi (legalformal) untuk memberikan pendidikan formal kepada masyarakat Bantul. Dengan menduduki posisi strategis tersebut maka akan memudahkan bagi kedua ormas Islam tersebut untuk berdakwah meskipun secara tersirat dalam menyebarkan ideologi keagamaan yang mereka anut. Tujuan itu akan mudah direalisasikan manakala orang nomor satu di dinas pendidikan dijabat oleh kader dari salah satu ormas tersebut.

Untuk mewujudkan keinginan itu maka kedua ormas tersebut menggunakan cara-cara yang berbeda. Nahdatul Ulama (NU) menyadari bahwa selama ini kedudukan atau posisi mereka dalam percaturan politik pendidikan (formal) di Bantul masih tergolong kecil. Hal tersebut dapat diketahui dari sedikitnya jumlah pejabat struktural di dinas pendidikan yang berasal dari NU. Selain itu masih ditambah adanya kenyataan bahwa peran NU dalam penyelenggaraan pendidikan formal di Bantul juga masih tergolong rendah yang ditandai dengan sedikitnya sekolah-sekolah di bawah yayasan Ma'arif NU yang mampu eksis di Bantul.

Hal tersebut disadari betul oleh NU sehingga mereka berkeyakinan bahwa untuk dapat mendudukkan kadernya sebagai kepala dinas pendidikan maka diperlukan langkah-langkah politik yang dapat mendongkrak bargaining position mereka di mata Bupati selaku pengambil keputusan. Nahdlatul Ulama (NU) melakukan manuver politik dengan banyak melakukan lobi-lobi politik kepada Bupati. NU berani melakukan lobi-lobi politik dengan membawa modal adanya kedekatan Bupati dengan tokoh-tokoh NU Bantul. Tokoh-tokoh NU Bantul khususnya para kiai selama ini sangat concern mendukung Bupati baik saat pencalonan sebagai Bupati ataupun dukungan secara sosial dan kultural selama berjalannya roda pemerintahan. Dengan mengandalkan modal tersebut NU memiliki bargaining position yang tinggi di hadapan Bupati.

Selain itu untuk mempermudah perwujudan rencana tersebut pengurus NU juga melakukan "sowan" politik kepada Gubernur DIY. Manuver politik ini sebagai mana dinyatakan oleh salah satu pengurus PCNU Bantul:

Dalam mempejuangkan agar pak HG jadi kepala Dinas Pendidikan, saya ikut menemui dan melobi pak Bupati. Bahkan kami sowan ke pak Gubernur. Tujuan kami sowan ke Ngerso Dalem untuk untuk secara serius memperjuangkan pak HG agar jadi kadispen (HJ/6 Oktober 2010)". 
Langkah ini dilakukan oleh pengurus PCNU dengan pertimbangan bahwa jabatan kepala Dinas Pendidikan adalah tergolong sebagai jabatan eselon II yang fit and proper test-nya dilakukan oleh Gubernur. Oleh karena itu, apabila kelak keinginan mereka diterima Bupati dan diajukan ke Gubernur untuk dilakukan fit and proper test maka diharapkan calon yang mereka ajukan akan lebih mudah lolos karena telah "disowankan" atau dikenalkan terlebih dahulu.

Muhammadiyah mengambil langkah berbeda dengan NU. Secara tersirat ormas tersebut telah memegang status quo di Dinas Pendidikan dengan adanya kenyataan bahwa jabatan-jabatan struktural di Dinas Pendidikan Bantul selama beberapa dekade dijabat oleh kader mereka. Mereka berkeyakinan bahwa Bupati selaku pengambil keputusan tentu mempertimbangkan faktor tersebut dalam pengambilan keputusan.

Keyakinan pengurus PDM bahwa Muhammadiyah telah memiliki status quo di Dinas pendidikan dilatarbelakangi fakta bahwa ormas tersebut memiliki peran yang besar dalam penyelenggaraan pendidikan formal di Bantul. Besarnya peran salah satunya diketahui dengan banyaknya lembaga pendidikan formal di bawah yayasan Muhammadiyah yang bisa eksis di Bantul. Hal ini sebagaimana dinyatakan oleh ketua PDM Muhammadiyah Bantul, "Sudah selayaknya bupati mengakomodasi pejabat di Dinas Pendidikan karena Muhammadiyah paling banyak menyelenggarakan lembaga pendidikan jenjang dasar" (AM/9 Oktober 2010).

Kondisi itulah yang kemudian menumbuhkan keyakinan kuat bagi pengurus Muhammadiyah bahwa posisi kepala dinas pendidikan akan diberikan kepada kader dari Muhammadiyah sehingga mereka tidak perlu melakukan manuver-manuver politik sebagaimana yang dilakukan NU. Selain itu, pengurus meyakini selama ini Muhammadiyah juga berjasa dalam memberikan dukungan secara politis bagi kepemimpinan Bupati.

Kuatnya bargaining position dua ormas Islam tersebut menjadi pertimbangan utama bagi Bupati dalam mengambil keputusan. Kedua ormas tersebut memiliki basis masa yang sangat besar di Kabupaten Bantul. Besarnya basis masa tersebut secara politis sangat menguntungkan bagi pihak-pihak yang berkepentingan untuk mempertahankan legitimasi politik di mata masyarakat. Akan sangat berbahaya bagi Bupati manakala memutuskan untuk memberikan jabatan kepala dinas pendidikan kepada salah satu kader dari ormas tersebut karena dikhawatirkan akan menimbulkan kecemburuan salah satu ormas.

Apabila sampai terjadi kondisi tersebut maka sangat berbahaya bagi Bupati karena dikhawatirkan salah satu ormas akan menarik dukungan politisnya. Kondisi seperti itu dikhawatirkan akan menimbulkan instabilitas politis khususnya di intern dinas pendidikan. Oleh karena Bupati berkepentingan untuk mendapatkan dukungan politis dari kedua ormas tersebut untuk mempertahankan kekuasaan dan menjalankan pemerintahan maka perlu diambil win-win solution. Keputusan yang diambil Bupati yakni memisah dinas pendidikan menjadi dua dan masing-masing dikepalai oleh kader dari NU dan Muhammadiyah.

Diakomodasikannya aspirasi dari ormas Islam NU dan Muhammadiyah oleh pengambil keputusan juga menunjukkan bahwa untuk mencapai tujuannya secara efektif, maka kelompok-kelompok kepentingan harus memiliki hubunganhubungan langsung dengan pembuat keputusan. Secara kasat mata seolaholah mereka hanya ingin menyampaikan permasalahan dan keluhan-keluhan, tapi secara prinsip mereka pasti akan mempengaruhi struktur pembuatan keputusan-keputusan itu bila ia diperkenankan untuk bertemu dengan pengam- 
bil keputusan. Hal ini berarti dalam menyuarakan kepentingannya itu dapatlah dipahami bahwa mereka tidak saja ingin menyampaikan informasi-informasi tetapi juga berkeinginan agar pandangan mereka dapat dipahami dan dimengerti oleh pembuat keputusan yang relevan dengan kepentinganya.

Langkah politik pengambil keputusan yang mengakomodasi aspirasi kedua kelompok kepentingan juga mengindikasikan bahwa berkaitan dengan usulan kebijakan pembentukan dua dinas pendidikan keberadaan ormas Islam yakni Nahdatul Ulama (NU) dan Muhammadiyah merupakan faktor yang lebih berpengaruh daripada partai politik. Partai politik tidak menjadi variabel utama yang di pertimbangan pemerintah meskipun parpol dalam bentuk fraksi-fraksi di DPRD merupakan pihak yang memiliki hak prerogatif untuk memberikan persetujuan (legalisasi) terhadap usulan kebijakan yang dibuat pemerintah tersebut. Hal itu karena kekuatan politik di DPRD Bantul sudah mengerucut pada satu kekuatan koalisi pendukung pemerintah yang sudah menguasai lima puluh persen lebih kursi di parlemen sehingga secara otomatis eksekutif sudah mendapatkan legitimasi politik yang kuat di parlemen.

Pengajuan usulan kebijakan pembentukan dua dinas pendidikan menunjukkan bahwa keinginan untuk membuat kebijakan pendidikan tidak semata-mata didominasi oleh kepentingan pemerintah dan dinamika kekuatan politik formal tetapi kadang kala justru dari sebuah tuntutan sederhana berupa kontrol politik bidang pendidikan oleh ormas-ormas yang ada di masyarakat. Jadi stakeholder yang mempengaruhi dalam pengambilan kebijakan tidak semata-mata kelompok formal saja tetapi juga kelompok nonformal (nonpemerintah/nonstruktural, tidak resmi). Kelompok nonformal yang mempunyai pengaruh besar terhadap lahirnya kebijakan pembentukan dua dinas pendidikan adalah ormas keagamaan NU dan Muhammadiyah.

Proses politik pengajuan draft Raperda tentang pembentukan dua dinas pendidikan menuai pro dan kontra baik sebelum memasuki sistem politik formal atau setelah memasuki sistem politik formal. Sebelum memasuki sistem politik formal pihak yang pro adalah intern dinas pendidikan. Hal ini karena dengan usulan pembentukan dua SKPD tersebut berarti semakin memberi peluang staff untuk dapat menduduki jabatan struktural mengingat terbuka jabatan-jabatan struktural baru di dinas pendidikan. Sementara pihak yang kontra adalah Dinas Pengelolaan Keuangan dan Aset Daerah yang menilai kebijakan tersebut sebagai pemborosan anggaran dan tidak efisien. Meski ada resistensi dari intern eksekutif draf Raperda tersebut tetap berhasil masuk ke dalam sistem politik formal dan menjadi agenda kebijakan karena kuatnya pengusung ide dalam meyakinkan dan memberikan argumen yang logis dan rasional mengenai pentingnya kebijakan tersebut.

Proses politik yang terjadi dalam sistem politik formal di DPRD berlangsung secara dinamis. Pola interaksi politik antara legislatif dengan eksekutif ataupun antar sesama aktor politik di legislatif menunjukkan adanya dinamika politik yang terbuka dan selalu berubah mengikuti arus dan wacana politik yang berkembang. Proses politik di DPRD dengan agenda pembahasan draft Raperda pembentukan dinas-dinas daerah di lingkungan Pemerintah Daerah Kabupaten Bantul termasuk rencana pembentukan dua SKPD dinas pendidikan berlangsung selama 4 (empat) kali sidang paripurna.

Dalam sidang paripurna yang pertama praktis tidak terjadi suasana politik yang "panas" karena agendanya baru sebatas penyampaian nota pengantar dari eksekutif terkait Raperda tersebut. Dalam sidang paripurna yang kedua den- 
gan agenda penyampaian pemandangan umum fraksi-fraksi DPRD terhadap Raperda yang diajukan, dinamika politik mulai berjalan yang ditandai dengan adanya perbedaan pandangan antar fraksi terhadap Raperda yang diajukan.

Fraksi PDI Perjuangan memilih sikap hati-hati yang ditunjukan dengan tidak memberikan pandangan (no comment) terhadap rencana pembentukan dua dinas pendidikan. Hal ini dilakukan mengingat mereka adalah fraksi pendukung pemerintah sehingga harus hati-hati dalam mengambil sikap dengan terlebih dahulu mencermati peta politik yang berkembang agar tidak melakukan kesalahan yang dapat merugikan posisi mereka ataupun posisi politik pemerintah. Sikap yang sama juga dilakukan fraksi Partai Golkar yang juga merupakan fraksi pendukung pemerintah yakni memilih sikap no comment terhadap usulan pembentukan dua dinas pendidikan.

Sikap berbeda ditunjukan oleh fraksi PKS, fraksi PAN, dan fraksi PKB yang meminta eksekutif untuk menjelaskan alasan-alasan dan pertimbangan yang dipergunakan mengapa dinas pendidikan harus dipecah menjadi dua SKPD. Fraksi PKS dan fraksi PAN cenderung lebih berani menyatakan perbedaan sikap politik terhadap pemerintah mengingat mereka merupakan partai oposisi pemerintah. Sementara fraksi PKB meskipun fraksi pendukung pemerintah tetapi mereka mencoba untuk tetap kritis dalam menilai usulan-usulan kebijakan yang akan diambil oleh pemerintah. Dalam sidang paripurna kedua juga menetapkan pembentukan Pansus untuk mengkaji Raperda yang diajukan pemerintah, karena setiap Raperda usulan eksekutif yang sudah diterima secara resmi oleh DPRD harus dikaji terlebih dahulu sebelum sidang paripurna untuk mengambil keputusan akhir.

Sidang paripurna ketiga dilaksanakan dengan agenda penyampaian jawa- ban eksekutif terhadap pemandangan umum fraksi-fraksi di DPRD dan penyampaian hasil kajian Pansus terhadap Raperda yang diajukan oleh eksekutif. Dalam sidang tersebut eksekutif hanya menyampaikan pertimbangan-pertimbangan yang sifatnya normatif dan fungsional. Hal ini mengingat tidak mungkin alasan-alasan politis dapat dijadikan dan diterima sebagai pertimbangan dalam mengajukan usulan kebijakan pembentukan dua Dinas Pendidikan.

Sementara itu, pansus menyampaikan hasil kajiannya bahwa dalam internal anggota pansus juga tidak dicapai kesepakatan mengenai dasar hukum pembentukan dua dinas pendidikan. Hal ini merepresentasikan bahwa di DPRD terjadi perbedaan penafsiran mengenai dasar hukum yang dapat dipergunakan bahwa dalam satu bidang yang sama dapat dikelola oleh lebih dari satu SKPD (Dinas).

Sidang paripurna yang keempat dilaksanakan dengan agenda penyampaian pendapat akhir fraksi-fraksi di DPRD Kabupaten Bantul dan pengambilan keputusan terhadap Raperda yang diajukan. Dalam sidang tersebut fraksi PDIP dan fraksi PKB menyatakan mendukung usulan kebijakan pembentukan dua dinas pendidikan. Fraksi PDIP mendukung dengan pertimbangan normatif bahwa pembentukan dua dinas pendidikan tidak bertentangan dengan dasar hukum diatasnya dan pertimbangan fungsional yakni beban kerja dinas pendidikan yang terlalu berat. Sementara itu, fraksi PKB hanya mendukung berdasarkan pertimbangan normatif untuk meningkatkan mutu pendidikan. Dukungan dari kedua fraksi tersebut tidak dapat dilepaskan dari faktor politis mengingat keduanya merupakan fraksi pendukung pemerintah.

Sikap bertolak belakang ditunjukkan oleh fraksi PKS dan fraksi Partai Golkar yang bersikap menolak usulan kebijakan pembentukan dua dinas pendidikan. 
Fraksi PKS menolak usulan tersebut dengan pertimbangan normatif yakni ketidaksinkronan dengan peraturan perundang-undangan di atasnya dan pertimbangan fungsional yakni efektivitas dan efisiensi. Sikap fraksi PKS tersebut bisa dipahami mengingat posisi mereka adalah oposisi pemerintah sehingga wajar kalau mereka mencoba mengcounter usulan-usulan kebijakan yang diajukan pemerintah. Sementara fraksi Golkar hanya melihat pada efisiensi dan efektivitas secara kelembagaan. Sementara sikap berhati-hati dan tidak berani berkonflik ditunjukkan oleh fraksi PAN dan fraksi PKB yang mengambil sikap untuk tidak memberikan statement setuju atau tidak setuju (no comment).

Konstelasi politik tersebut mengalami perubahan yakni sikap fraksi Golkar yang menyatakan mendukung usulan kebijakan pembentukan dua dinas pendidikan. Perubahan tersebut terjadi setelah adanya mekanisme politik yang berjalan berupa lobi-lobi dan tawar menawar politik antar aktor politik. Akan tetapi kemufakatan bersama seluruh fraksi tetap tidak dapat tercapai karena fraksi PKS tetap pada pendirian awal untuk menolak usulan tersebut. Oleh karena itu, mekanisme voting dilaksanakan untuk mewujudkan konsensus politik terkait usulan kebijakan pembentukan dua dinas pendidikan. Hasil voting akhirnya memenangkan opsi menerima usulan pemerintah untuk membentuk dua dinas pendidikan.

\section{Implikasi Politik Pembentukan Dua Dinas Pendidikan di Kabupaten Ban- tul}

Proses politik di DPRD yang menghasilkan keputusan untuk membentuk dua dinas pendidikan membuat daya penekan (pressure) dan bargaining position fraksi PKS di parlemen menjadi semakin kuat dalam mengkritisi bidang pendidikan di Kabupaten Bantul. Hal tersebut mengingat posisi fraksi PKS sejak awal adalah sebagai pihak yang menolak rencana pembentukan dua dinas pendidikan. Oleh karena itu, apabila setelah dibentuk dua dinas pendidikan ternyata masih banyak problem-problem pendidikan di Kabupaten Bantul yang tidak dapat terselesaikan maka fraksi PKS memiliki "hak politis" untuk mengkritik pihak-pihakyang dulu mendukung kebijakan tersebut.

Selain itu penetapan kebijakan pembentukan dua dinas pendidikan dan penentuan pemegang jabatan kepala dinas berpengaruh pada pola birokratisasi di kedua lembaga tersebut. Pengangkatan pejabat kepala dinas yang masing-masing merupakan kader dari $\mathrm{NU}$ dan $\mathrm{Mu}-$ hammadiyah pada akhirnya berdampak systemic dalam pola penempatan pejabat struktural pada birokrasi di kedua lembaga tersebut. Kepala dinas terpilih pada akhirnya mengangkat para pejabat struktural di lembaga yang dia pimpin salah satunya dengan pertimbangan faktor kesamaan golongan yang dalam bahasa politiknya dikenal dengan istilah spoil system atau patronage system.

Kondisi tersebut berakibat pada terjadinya gejala Jacsonisasi birokrasi". Adanya gejala Jacsonisasi dalam penempatan pejabat struktural di dua dinas pendidikan ditunjukan dengan kenyataan bahwa setelah Dinas Pendidikan Dasar dikepalai kader Muhammadiyah maka banyak kader Muhammadiyah yang menduduki jabatan struktural di Dikdas dan setelah Dinas Pendidikan Menengah dan Non Formal dikepalai kader NU maka banyak kader NU yang menduduki jabatan struktural di Dikemenof.

Pola penempatan pejabat-pejabat struktural di dua dinas pendidikan juga mengindikasikan masih adanya model birokrasi patrimonial. Pola hubungan yang terjadi lebih bersifat personal. Faktor kedekatan dan loyalitas pribadi lebih mengedepan daripada aturan-aturan legal formal. Oleh karenanya, yang terjadi 
lalu muncul hubungan bersifat personal, berdasarkan pertemanan, dan like and dislike dalam promosi jabatan. Dengan demikian model birokrasi ala Weberian yang menekankan profesionalisme, impersonal, dan legal formal masih belum eksis dalam tubuh birokrasi pada dua dinas pendidikan di Kabupaten Bantul.

Penetapan kebijakan pembentukan dua dinas pendidikan juga berimplikasi pada besaran anggaran yang harus dikeluarkan pemerintah. Pembentukan lembaga baru akan diikuti dengan penambahan sarana dan prasanana baru (gedung, mobil dinas, dll) yang berdampak pada penambahan biaya operasional yang harus dikeluarkan (perawatan, listrik, air, BBM, dll). Selain itu terbentuknya lembaga baru diikuti munculnya bidang atau subbidang yang baru pada masingmasing dinas sehingga jumlah staf (pegawai) dan pejabat struktural (eselon) mengalami penambahan karena jumlah yang ada sebelumnya tidak mampu mencukupi kebutuhan. Hal tersebut membuat semakin besarnya beban pembiayaan yang harus dikeluarkan pemerintah.

Sementara itu pada saat yang bersamaan penetapan kebijakan pembentukan dua dinas pendidikan kurang diimbangi dengan kesiapan pemerintah daerah dalam hal sosialisasi kebijakan. Hal tersebut berdampak pada sering terjadinya miss komunikasi antara dua dinas pendidikan dengan masyarakat ataupun dengan lembaga-lembaga lain. Masyarakat masih belum memahami kalau pengelolaan bidang pendidikan di Bantul dilakukan oleh dua SKPD (Dinas). Keberadaan dua lembaga dinas pendidikan membuat masyarakat kebingungan apabila ingin mengurus sesuatu hal apakah harus berhubungan dengan Dinas Pendidikan Dasar atau Dinas Pendidikan Menengah dan Non Formal. Akibatnya sebagian masyarakat yang datang dan ingin mengurus sesuatu hal yang sebenarnya berhubungan den- gan Dikdas tetapi justru "salah tempat" datang ke Dikemenof atau sebaliknya.

Kendala serupa masih sering dialami lembaga-lembaga eksternal di luar Kabupaten Bantul manakala akan berhubungan dan berkoordinasi dengan Dinas Pendidikan Bantul. Undangan rapat-rapat dan koordinasi dari lembaga tingkat propinsi ataupun tingkat pusat jumlahnya hanya satu dan hanya ditujukan kepada dinas pendidikan Kabupaten Bantul. Akibatnya undangan sering "nyasar" di tempat yang kurang tepat, misalnya undangan yang seharusnya lebih tepat ditujukan ke Dikdas ternyata keliru masuk ke Dikmenof dan juga sebaliknya. Undangan yang jumlahnya hanya satu tersebut kadangkala menimbulkan permasalahan terkait pihak mana yang harus menerima undangan dan berangkat atas nama SKPD pengelola bidang pendidikan di Kabupaten Bantul.

Meskipun terjadi beberapa permasalahan sebagai dampak pembentukan dua SKPD dinas pendidikan, akan tetapi permasalahan-permasalahan yang ada tidak sampai membuat terjadinya konflik-konflik atau menyebabkan munculnya gejala ego sektoral dari masing-masing dinas pendidikan. Hal ini karena stakeholders dari masing-masing lembaga menyadari kuatnya kedekatan historis dan kultural antara kedua lembaga sehingga membuat komunikasi dan koordinasi antara kedua lembaga dapat berjalan baik dan lancar.

Pembentukan dua dinas pendidikan juga memiliki dampak positif dalam upaya pecapaian prestasi pendidikan di Kabupaten Bantul. Adanya dua dinas pendidikan memberi peran signifikan dalam pencapaian prestasi ujian nasional (UN) di Bantul yang dalam 3 (tiga) tahun terakhir menunjukkan grafik meningkat dan selalu menjadi yang tertinggi di Provinsi DIY. Selain memberi peran signifikan dalam peningkatan nilai UN, adanya dua Dinas Pendidikan juga membuat tugas-tugas lain yang terkait 
pendidikan bisa lebih cepat ditangani. Hal-hal yang terkait peningkatan mutu guru, sertifikasi guru, bahkan upaya peningkatan kualifikasi akademik guru bisa lebih terkontrol dan terkoordinasi dengan baik.

\section{SIMPULAN}

Berdasarkan kajian terhadap temuan penelitian dapat ditarik beberapa kesimpulan sebagai berikut:

1. Latar belakang pembentukan dua dinas pendidikan di Kabupaten Bantul dapat dilihat dari 3 (tiga) perspektif yaitu:

a. Perspektif politik: Pembentukan dua dinas pendidikan dilatarbelakangi adanya motif politik Bupati untuk memberikan perimbangan kekuasaan dalam bidang pendidikan bagi dua kelompok kepentingan yakni Nahdatul Ulama (NU) dan Muhammadiyah.

b. Perspektif normatif: Pembentukan dua dinas pendidikan dilatarbelakangi adanya kewenangan yuridis formal bagi pemerintah daerah untuk mengatur, mengurus, dan mengelola bidang pendidikan sesuai karakterisrik, kemampuan, dan kebutuhan serta merupakan bentuk komitmen Pemda Bantul dalam memajukan pendidikan daerah sesuai amanat Rencana Pembangunan Jangka Menengah Daerah (RPJMD).

c. Perspektif fungsional: Pembentukan dua dinas pendidikan dilatarbelakangi rendahnya kinerja dinas pendidikan ketika masih menjadi satu lembaga yang dianggap tidak mampu menjalankan tugas pokok dan fungsinya (tupoksi) dengan baik.

2. Dinamika politik dalam proses pembentukan dua dinas pendidikan di Kabupaten Bantul menunjukkan bahwa kekuatan politik informal dan kekuatan politik formal memiliki peran yang sama kuat dalam mempengaruhi proses pengambilan kebijakan pembentukan dua dinas pendidikan.

3. Pembentukan dua dinas pendidikan di Kabupaten Bantul secara politis berimp- likasi pada semakin besarnya anggaran yang harus dikeluarkan pemerintah daerah, membuat semakin berkembangnya gejala Jacsonisasi birokrasi dan birokrasi patrimonial, dan membuat semakin kuatnya daya penekan (pressure) dan posisi tawar (bargaining position) fraksi yang dulu menolak rencana pembentukan dua dinas pendidikan dalam mengkritisi bidang pendidikan di Kabupaten Bantul. Akan tetapi pembentukan dua dinas pendidikan juga memberi peran cukup signifikan dalam meningkatkan prestasi pendidikan di Kabupaten Bantul.

\section{DAFTAR PUSTAKA}

Ace Suryadi dan HAR Tilaar. (1993). Analisis Kebijakan Pendidikan: Suatu Pengantar. Bandung: Remaja Rosdakarya.

AG Subarsono. (2009). Analisis Kebijakan Publik: Konsep, Teori dan Aplikasi. Yogyakarta: Pustaka Pelajar.

Budi Winarno. (2005). Teori dan Proses Kebijakan Publik. Yogyakarta: Media Presindo.

Didi Supriyadi. (2009). "Pengaruh desentralisasi pendidikan dasar terhadap kualitas pendidikandi kabupaten Jembrana propinsi Bali".Jurnal Kependidikan (Nomor 1tahun XXXIX). Hlm. 35-58.

Lili Romli. (2007). Potret Otonomi Daerah dan Wakil Rakyat di Tingkat Lokal. Yogyakarta: Pustaka Pelajar.

Miriam Budiardjo. (2008). Memahami Ilmu Politik (Edisi Revisi). Jakarta: Gramedia Pustaka Utama.

Ramlan Surbakti. (1992). Memahami Ilmu Politik. Jakarta: Gramedia Widiasarana Indonesia.

Soenarko SD. (2000). Public Policy: Pengertian Pokok untuk Memahami dan Analisa Kebijaksanaan Pemerintah. Surabaya: Airlangga University Press.

Sugiyono. (2009). Metode Penelitian Kuantitatif, Kualitatif dan $R \& D$. Bandung: Alfabeta.

Toni Andrianus Pito dkk. (2006). Mengenal Teori-Teori Politik: Dari Sistem Politik Sampai Korupsi. Bandung: Nuansa. 